\title{
Skica kristološko-trinitarne hermeneutike pakla i dužnosti nade u spas svih ljudi u misli H. U. von Balthasara
}

\author{
BorIS VULIĆ* \\ • https://doi.org/10.31823/d.26.4.2 • \\ UDK: 27-188.7-423.79-05 Balthasar, H.U. • Izvorni znanstveni rad \\ Primljeno: 4. svibnja 2018. • Prihvaćeno: 6. prosinca 2018.
}

* Doc. dr. sc. Boris Vulić, Katolički bogoslovni fakultet u Đakovu Sveučilišta J.J. Strossmayera u Osijeku, P. Preradovića 17, p. p. 54, 31400 Đakovo, Hrvatska, vulic@me.com

Sažetak: Čini se da je posljednja velika uistinu teološka diskusija vođena oko teze švicarskoga teologa Hansa Ursa von Balthasara o nadi u spas svih ljudi. Nakana je ovoga clanka ponajprije podsjetiti na temeljne sadržaje toga prijedloga. Tako u prvom poglavlju prikazujemo novozavjetna mjesta $i$ teološke momente koje ovaj švicarski teolog uzima za polazišta i opravdanja svoga uvjerenja o dužnosti kršćanske nade u sveopći spas. Ipak, temeljna je teza članka da je konačna pozadina takve nade Balthasarova kristološko-trinitarna hermeneutika pakla, u kojoj pakao postaje poduhvaćen Kristom i zato kristološko mjesto milosti. Upravo se ta konačna pozadina, čiju skicu donosimo u drugom poglavlju, u većini prikaza na hrvatskom jeziku propušta uočiti kao temeljna premisa nade u spas svih ljudi. Spomenuta originalna hermeneutika dovela je Balthasara do uvjerenja da Božje milosrde po Kristovu križu zauzima mjesto pravednosti, čime se bavimo u trećem i ujedno posljednjem poglavlju članka. U zaključnim mislima ukazujemo na važne doprinose Balthasarovih promišljanja o sveopćoj nadi, poput ozbiljnosti vjerske istine o paklu, osobnom karakteru mogućnosti pakla (pakao za mene) te o Bogu koji je uvijek posljednja čovjekova stvarnost, pa i onda kad je vječno izgubljen. Takoder otkrivamo i neka dvojbena ili problematična mjesta Balthasarove misli koja valja prepoznati kao nove perspektive za daljnja kritička istraživanja.

Ključne riječi: Hans Urs von Balthasar, nada, sveopći spas, Trojstvo, Kristov križ, pakao, milosrde, pravednost. 
Ljubite neprijatelje, molite za one koji vas progone da budete sinovi svoga Oca koji je na nebesima, jer on daje da sunce njegovo izlazi nad zlima i dobrima i da kiša pada pravednicima i nepravednicima.

(Mt 5, 44-45)

\section{Uvod}

Čini se da je zadnja teološka teza koja je izazvala veliku teološku raspravu širokih razmjera bila upravo teza švicarskoga teologa Hansa Ursa von Balthasara (1905. - 1988.) o nadi u spas svih ljudi. Teološka drama oko toga i danas životari kroz njezino kritičko vrjednovanje, s cijelom plejadom raznih pristupa ${ }^{1}$ - od odviše sumornih rasprava na marginama teološke zamijećenosti sve do doktorskih disertacija i ozbiljnih studija koje tu tezu žele iznova promisliti i osvježiti. ${ }^{2}$

To na neki način i mi želimo ovim promišljanjima. U prvom ćemo dijelu članka prikazati Balthasarovu teološko-povijesnu analizu profiliranja kršćanske nade u spas svih ljudi, a u drugom ćemo istražiti temeljne obrise konačne teološke pozadine takve nade. U trećem ćemo dijelu izdvojiti jedno od središnjih pitanja važnih za našu temu, a to je odnos između Božjega milosrđa i pravednosti, i to onako kako taj odnos vidi švicarski teolog.

Kao točku koja na poseban način izdvaja Balthasarov stav o nadi u spas svih ljudi izdvajamo 1985. godinu (dakle tri godine prije njegove smrti). Te je godine u Rimu održan simpozij posvećen Adrienni von Speyr, koja je, kako je uvelike poznato, ostavila jedinstveni trag u opusu našega teologa. Balthasar je tom prigodom jasno izrazio svoju tezu o nadi u spas svih ljudi, čije je premise razvijao u svojim ranijim djelima. Tada je spomenuo i da bi pakao mogao biti prazan. ${ }^{3}$ To je izazvalo žestoke

\footnotetext{
${ }^{1}$ Vidi više u: J. AMBAUM, Speranza di un inferno vuoto. Restaurazione di tutte le cose? La speranza della salvezza secondo Hansu Urs von Balthasar, u: Comuunio, tal. izdanje, 115(1991.), 52-69.; A. DULLES, The Population of Hell, na: https://www.firstthings.com/article/2003/05/the-population-of-hell; hr. prijevod na: https://www.bitno.net/academicus/teologija/tko-ide-u-pakao-ljudiu-paklu-je-li-pakao-pun-ili-prazan/ (8. 3. 2018.); I. ANDEREGGEN, Inferno vuoto? Un confronto con l'infernologia di Hans Urs von Balthasar, u: Fides Catholica. Rivista di Apologetica teologica 4(2009.)2, 415-444. Potonji članak ulazi u red najtežih optužbi na račun Balthasarova prijedloga nade u spas svih ljudi.

${ }^{2}$ Ističemo jedan takav doktorski rad: A. M. MINUTELLA, L'escatologia cristologico-trinitaria di Hans Urs von Balthasar, Venezia, 2014. Središnji dio te disertacije upravo je pitanje nade u spas svih ljudi.

${ }^{3}$ Očito su pitanja koja su postavljena Balthasaru bila motivirana tezom izraženom u članku koji je objavljen šest dana prije početka spomenutoga simpozija, čini se bez autorova znanja: H. U. von BALTHASAR, Kleine Kathechese über die Hölle, u: L'Osservatore Romano, tjedno izdanje na njemačkom jeziku, 21. rujna 1984., 1-2.
} 
reakcije teologa, sve do optužbe da je novi Origen, koji oživljava osuđenu apokatastazu. ${ }^{4}$ Stoga se naš teolog odlučuje obraniti onako kako najbolje zna - u tri je godine napisao tri djelca u kojima pojašnjava svoja uvjerenja i uvide glede nade $u$ spas svih ljudi i kršćanske obveze spram takve nade. ${ }^{5}$

Sad ćemo pobliže osvijetliti njegovu tezu o mogućnosti praznoga pakla ili ipak, ispravnije rečeno, tezu o nadi u spas svih ljudi.

\section{Mjesto nade u spas svih ljudi u životu Crkve}

Uz istinu da smo svi pod Božjim sudom, za Balthasara je važno i razlikovanje prema kojemu u Novome zavjetu postoje dva reda izjava, koji se paralelno pojavljuju, a koje nije moguće pomiriti u skladnu sintezu, kao što nije moguće jedan red izjava pretpostaviti drugom ili pak jedan red izjava objektivizirati, zaboravljajući na onaj drugi. ${ }^{6} \mathrm{U}$ prvi red ulazi novozavjetni govor o vječnoj propasti, koji se, tragom egzegetskih istraživanja, pripisuje predpashalnom Isusu. Ti navještaji nisu precizne reportaže o konačnom ishodu, nego opomene da su svi ljudi pozvani odrediti se spram Boga Isusa Krista. Također, prema našem teologu, ti nas navještaji čuvaju od površnoga zaključka da će na kraju sve biti dobro samim tim što je kraj dosegnut.

Drugi red sadrži objavu Božje sveopće spasenjske volje, koja u postpashalnoj perspektivi odražava i tumači cijeli Kristov život i nauk te pritom nedvojbeno objavljuje da se otajstvo spasenja tiče svih ljudi. Tu je dakle težište na riječi svi, što se

\footnotetext{
${ }^{4}$ Među prvim negativnim reakcijama bile su: G. HERMES, Ist die Hölle leer?, u: Der Fels 15(1984.), 250-256.; ISTI, Hoffnung auf das Heil aller? Bei H. U. von Balthasar nichts Neues, u: Der Fels 15(1984.), 316-320.; H. SCHAUF, Die ewige Verwerfung in neueren und älteren kirchlichen Verlautbarungen, u: Theologisches 17(1985.), 6253-6258.; ISTI, Selbstverzehrung des Bösen? Einige Fragen an H. U. von Balthasar und seinen Kommentar zur Apokalypse des hl. Johannes, u: Theologisches 17(1985.), 6394-6396. Teolog Vito Mancuso, iako svjestan da se Balthasar nikad s tim ne bi složio (?!), švicarskoga teologa uporno određuje kao predstavnika Origenove apokatastaze, čak i radikalnijega predstavnika od samoga Origena: V. MANCUSO, L'anima e il suo destino, Milano, 2007., 244-248.

${ }^{5}$ H. U. von BALTHASAR, Sperare per tutti (1986.) - Breve discorso sull'inferno (1987.) - Apocatastasi (1988.), Milano, 1997. Godina iza naslova pojedinoga djela označava godinu objave originala na njemačkom jeziku. Kasnije u radu navodit ćemo samo pojedino djelo, bez naznake autora. Ta tri djelca u talijanskom prijevodu, koje nam je dostupno i kojim ćemo se ovdje služiti, izišla su u jedinstvenom izdanju. Napominjemo da talijanski prijevod prvoga naslova nije posve vjeran naslovu originala: Was dürfen wir hoffen? (Čemu se smijemo nadati?). Zanimljivo je primijetiti da je talijanski naslov, slučajno ili ne, zapravo koncipiran tako da daje odgovor na pitanje postavljeno u originalnom, njemačkom naslovu!

${ }^{6}$ Usp. Sperare per tutti, 23s.; Breve discorso sull'inferno, 130.; Apocatastasi, 166.
} 
posebno jednoznačno vidi u Prvoj poslanici Timoteju: $\gg[$ Bog] koji hoće da se svi ljudi spase i dođu do spoznanja istine.« $(2,4-5){ }^{7}$

Nakon kratke novozavjetne analize Balthasar prelazi na istraživanje ranokršćanske misli. Prvo se posvećuje Origenu, koji je, kako je poznato, vrlo važan, općenito gledano, za Balthasarovu misao. Prema analizi našega teologa, Origen iz grčko-antičke kružne predodžbe vremena ${ }^{8} \mathrm{i}$ ideje prema kojoj kraj mora odgovarati početku izvodi (tek) hipotezu o nadi da će Krist ponovno vratiti sve stvorenje Ocu. ${ }^{9}$ Na pitanje mogu li se i demoni na kraju obratiti Balthasar uočava da Origen isprva odgovor prepušta čitatelju, a kasnije odlučno odbija da je naučavao đavlovo spasenje. Origen se međutim ozbiljno okreće nadi u spas svih ljudi, ali ipak drži da je za većinu kršćana, ponajprije zbog pedagoških razloga, dovoljno da znaju da će grješnici biti kažnjeni. Ići dalje od toga nije dobro jer se tako vjernike može navesti da čine zlo i da zaborave na kazne kojima mogu biti kažnjeni. ${ }^{10}$ Iako se ista logika nade u sveopći spas ljudi može pronaći i kod drugih crkvenih otaca (Klement Aleksandrijski, Grgur iz Nise, rani Jeronim i dr.), Crkva je, tri stoljeća poslije, osudila samo Origena.

Točka prekretnica kojom se napušta sveopća nada u spas svih ljudi, prema Balthasaru, započinje sa sv. Augustinom, jednim od najvažnijih $\gg$ navjestitelja pakla $\ll{ }^{11}$ ili infernalista - paklista, kako ih Balthasar naziva, koji se počinju intenzivno baviti pitanjima poput onih o vrsti vječnih muka, o realnosti i materijalnosti pakla. $\mathrm{Za}$ švicarskoga je teologa Augustin prvi crkveni otac koji posve jasno zna ishod božanskoga suda jer zastupa tezu da će u paklu završiti, uz pobunjene anđele, i zli ljudi, i to $\gg$ cjelokupna gromada ljudskoga roda $\ll .{ }^{12}$ Glede molitve za spas svih Balthasar uočava kako Augustin drži da se ne bi trebalo moliti za one koji su zli, kad bi se znalo koji su to, jednako kao što se ne moli ni za đavla. Budući da ne znamo koji su osuđeni, trebamo moliti za sve ljude, uključujući i svoje neprijatelje, ali znamo da ne ćemo biti uslišani za sve. ${ }^{13}$

\footnotetext{
${ }^{7}$ Kurziv je naš.

${ }^{8}$ Za Balthasara je jako važno razumjeti da i sama Biblija uz linearno shvaćanje vremena poznaje i kružno shvaćeno vrijeme, posebno pod vidom povratka, obnove, ponovne uspostave i sl. Istu logiku slijede i rani crkveni oci. Usp. Apocatastasi, 159-166.

${ }_{9}^{9}$ Usp. isto, 167.

${ }^{10}$ Usp. isto, 170.

${ }^{11}$ Usp. Sperare per tutti, 37.

${ }^{12}$ AUGUSTIN, De Civitate Dei. O državi Božjoj, III, 21, 12, Zagreb, 1996.

${ }^{13}$ Vidi više u: Isto.
} 
Ipak, sam Balthasar ukazuje na to da bi bilo posve krivo $\gg$ bogatu i poliedarsku $\ll{ }^{14}$ Augustinovu teologiju svesti samo na pitanje pakla. Svakako treba uzeti u obzir da se Augustin s pravom bori protiv devijacija svoga vremena, ali za to, prema Balthasaru, izabire krivi način jer u razumijevanju pakla prelazi granicu danu božanskom objavom te dovodi do $\gg$ strašnog ograničenja kršćanske nade $\ll .{ }^{15}$

Sljedeća točka prekretnica razumijevanju sveopće nade u spas svih ljudi jest sv. Toma Akvinski. Naime Toma drži da se nada sama po sebi ne može odnositi na drugoga, ali ako joj je pretpostavka ljubav, koja ujedinjuje onoga koji se nada i drugoga, onda se treba nadati i za drugoga. I kao što je ljubav kojom netko ljubi Boga, sebe samoga i bližnjega ista ljubav, tako je i nada kojom se netko nada za sebe samoga i za drugoga ista krjepost nade. Također Akvinac podsjeća da se mora vjerovati da se može i postići ono čemu se nada i za što se moli. Prema tomu velika novost sv. Tome za Balthasara jest univerzalnost nade koja proizlazi iz univerzalnosti ljubavi, koja obuhvaća čak i neprijatelje. Međutim mora se također primijetiti da je riječ o univerzalnosti koja je ipak više govor o drugom i drugima, a ne toliko jasno o svima. Švicarski teolog potom prelazi na sljedeće područje povijesti kršćanskoga duha svjedočanstva mističnih iskustava, kojima poklanja posebnu pozornost upravo pod vidom nade u spas svih ljudi te osobnom karakteru mogućnosti pakla jer

»' pakao' je ono što me osobno čeka - ne hipotetski, nego s punim pravom ono ispred čega se trebam postaviti s radikalnom ozbiljnošću, bez da mi pogled odluta na druge. ( ... A Ako objektiviziram pakao, ako od njega napravim teološko-znanstveni 'objekt' tada počinjem računati koliki odlaze u njega, a koliki ga uspijevaju izbjeći. $U$ tom se trenutku sve mijenja: pakao više nije moj pakao, nego je ono što čeka 'druge', dok ću ja, zahvaljujući Bogu, od njega nekako pobjeći. ${ }^{16}$

Na temelju izabranih iskustava (osobito Terezije iz Lisieuxa, Terezije Avilske, Ivana od Križa) ${ }^{17}$ za Balthasara je očito da se iskustva viđenja ili boravka u paklu rađaju iz goruće ljubavi spram Kristova križa, iz želje da se pati zajedno s Kristom za spas svih ljudi i tako ima barem mali udio u Kristovoj napuštenosti na križu, čineći sve kako bi se spasila barem jedna duša. Zato neka mistična viđenja opisuju ljude koji idu prema paklu, sve u gorljivoj želji da se dokinu viđene paklene muke, odnosno

\footnotetext{
${ }^{14}$ Sperare per tutti, 50.

${ }^{15}$ Isto, 53.

${ }^{16}$ Breve discorso sull'inferno, 137. Kurziv je naš. Balthasar ironično primjećuje da su nam u paklu uvijek drugi te navodi za primjer Ivana Groznog, Staljina i Hitlera koji, prema dominantnoj forma mentis, sigurno moraju biti u paklu. Usp. isto, 138.

${ }^{17}$ Usp. Sperare per tutti, 71s.; Breve discorso sull'inferno, 136s.; Apocatastasi, $173 \mathrm{~s}$.
} 
da pakao bude uništen i da nijedna duša u njemu ne završi. To je ujedno za Balthasara jedini smisao takvih privatnih objava, a ne uvjerenje da se $s$ tim dušama više ništa ne može učiniti. ${ }^{18}$

Balthasarova analiza mističnih iskustava pakla ponajbolje ukazuje na konačnu pozadinu sveopće nade u spas svih ljudi i to onako kako ju vidi naš teolog.

\section{Poduhvaćeni pakao}

Možemo reći ovako: u trima spomenutim djelcima Balthasar sustavno razvija pitanja i potpitanja vezana za nadu u spas svih, ali njezinu konačnu pozadinu odredio je u svojim ranijim djelima. Posebno tu mislimo na Teodramatiku (orig. 1983.), ${ }^{19}$ kao i na ranije djelo Mysterium Paschale (orig. 1969.). ${ }^{20}$

Kako je poznato, teologija Velike subote predstavlja ključ cijele Balthasarove teologije, a to znači da ona ima reperkusije i na razumijevanje nade u spas svih ljudi. ${ }^{21}$ Središnji sloj njegove teologije Velike subote jest promišljanje otajstva iz Vjerovanja o Kristovu silasku nad pakao. Taj je članak, koji naš teolog radije naziva »Put k mrtvima «, u crkvenoj tradiciji shvaćen aktivno - Krist je na Veliku subotu sišao nad pakao, kao pobjednik nad smrću i kao onaj koji je u nebo uveo starozavjetne vjerne. ${ }^{22}$ Balthasar ide korak dalje te otajstvo Velike subote promatra bitno pod pasivnim, solidarno neaktivnim, odnosno kenotičko-dramatičnim vidom.

\footnotetext{
${ }^{18}$ Usp. Breve discorso sull'inferno, 152.

${ }^{19}$ Usp. H. U. von BALTHASAR, Teodrammatica. L'ultimo atto, V, Milano, ${ }^{2} 1995$., osobito 229s.

${ }^{20}$ Usp. H. U. von BALTHASAR, Mysterium Paschale. Sveto trodnevlje smrti, pokopa i uskrsnuća našega Spasitelja, Zagreb, 1993., osobito 119s.

${ }^{21}$ Kad je riječ o Balthasarovoj nadi u spas svih ljudi u literaturi dostupnoj na našem jeziku ne ukazuje se na njezinu konačnu pozadinu, koju valja tražiti izvan triju djelca koja smo gore prikazali. Pod tim vidom dragocjena je iznimka dana u: I. RAGUŽ, Pakao i nada u spas svih ljudi, u: ISTI, Vesperae sapientiae christianae. Tribine 3, Zagreb, 2008., 89-102. Uvidi koje slijede oslanjaju se na navedeno djelo, u kojem se mogu pronaći i izabrani te prevedeni izvorni citati i druge reference te na djelo: A. M. MINUTELLA, L'escatologia cristologico-trinitaria di Hans Urs von Balthasar, 103-186. Upućujemo i na: L. F. LADARIA, Il Dio vero e vivo. Il mistero della Trinità, Casale Monferrato, ${ }^{32004 .,}$ 92-95.; L. SABBIONI, Giudizio e salvezza nell'escatologia di Hans Urs von Balthasar, Milano, 1990.; I. IVANDA, Das Problem des Bösen in der Theologie Hans Urs von Balthasars, Roma, 2001.; N. J. HEALY, The Eschatology of Hans Urs von Balthasar. Being as Communion, Oxford, 2005.

${ }^{22}$ Vidi: Katekizam Katoličke Crkve, Zagreb, 2016., br. 631-637. Tu se u br. 633 naučava: »Isus nije sišao nad pakao da oslobodi proklete ni da razori pakao prokletstva, nego da oslobodi pravedne koji su mu prethodili.« Sustavni prikazi toga članka vjere u: G. ANCONA, Disceso agli inferi. Storia e interpretazione di un articolo di fede, Roma, 1999. (o Balthasaru: 105-112.); P. ZAVATTA, La teologia del Sabato santo, Roma, 2006.
} 
Na putu prema mrtvima Krist je u otajstvu Velike subote sišao $u$ sam pakao, mrtav je zajedno s osuđenima koji su u paklu. Sin - i to kao od Oca napušteni Sin, dijeli pakao s grješnicima: »Njega koji ne okusi grijeha Bog za nas grijehom učini da mi budemo pravednost Božja u njemu.« (2 Kor 5, 21). Iz toga proizlazi da Krist nije samo izvanjski solidaran s osuđenima na pakao nego napose iznutra. Raspeti i umrli Krist u samom svom biću iskusio je stanje napuštenosti od Oca, što i jest pakao. To Kristovo iskustvo bogonapuštenosti jedinstveno je samim tim što se događa u biću u kojem je božanska narav hipostatski sjedinjena s ljudskom. Krist, čovjek božanske Boli, ${ }^{23}$ dakle pati mnogo dublje od bilo kojega drugoga čovjeka, uključujući i one koji su osuđeni na pakao. Međutim to nije i njegovo konačno stanje jer smrt za Sina nije prekid života, nego pobjednička forma očitovanja života, očitovana kao uskrsnuće i uzašašće $\mathrm{k} O \mathrm{cu}$.

Kristovo iskustvo pakla i napuštenosti od Oca zapravo je povijesno-spasenjska epifanija pra-kenoze, odnosno beskonačne božanske razlike između Oca i Sina u samom Trojstvu - Otac se potpuno predaje Sinu, odriče se, da tako kažemo, sebe i u Duhu Svetome napušta svoje božanstvo, na što Sin, opet u Duhu, slobodno i poslušno uzvraća istim uzdarjem. Taj unutartrojstveni dinamizam odreknuća, udaljenosti i napuštanja jest prostor distance između Oca i Sina, koja je za Balthasara uvjet svake druge razlike, svakoga drugoga postojanja, uključujući i mogućnost postojanja stvorenoga i spašenoga svijeta, ali i mogućnost grijeha, odnosno slobodnoga i definitivnoga čovjekova ne Bogu.

Krist slobodno i poslušno prihvaća pakao iz ljubavi, a ne, kao ljudi, zbog grijeha. On ulazi u pakao i u njega trajno unosi Božju dobrotu i ljubav te ga upravo tako nadilazi, odnosno poduhvaća (za Balthasara ključan pojam!) odozdo i iznutra, a to znači i dokida kao stanje radikalne i beskonačne bogonapuštenosti. Stoga čovjek koji je odlučio Boga ostaviti vječno iza leđa sada susreće Krista ispred sebe i nužno mu ide ususret. »Tako grešnik, također kad ne zna ili ne želi, može ići prema Bogu. ${ }^{24}$ Pakao je time postao kristološki pojam i teološko mjesto.

Za teologiju i duhovnost krajnja posljedica poduhvaćenosti zla, grijeha i pakla jest dužnost kršćanske nade u spas svih ljudi. Za Balthasara drugoga puta nema. Naravno, mi ne znamo hoće li svi biti spašeni, ali se zbog Kristova otajstva Velike subote i njegova uskrsnuća moramo nadati da će svi ljudi biti spašeni, odnosno da će svako ljudsko slobodno ne Bogu biti spasonosno plodno poduhvaćeno Kristovim križem, a to znači Božjom ljubavlju koja je u otajstvu Velike subote trajno obuhvatila pakao (ne ponovno uspostavila izvorno!) i nadvladala (ne integrirala!) zlo.

\footnotetext{
${ }^{23}$ Balthasaru je posebno važna ta sintagma, koju je pronašao kod M. Blondela. Usp. Sperare per tutti, 87.

${ }^{24}$ Teodrammatica, V, 266.
} 
Sad ćemo se kratko posvetiti jednom od središnjih pitanja sveopće nade, a to je odnos između Božjega milosrđa i njegove pravednosti.

\section{Odnos Božjega milosrđa i pravednosti}

I kod pitanja odnosa Božjega milosrđa i njegove pravednosti u Svetom pismu nalazimo dva reda izjava - one o Božjem milosrđu i one o njegovoj pravednosti, koje je teško staviti u harmoniju. Žestoki protivnik strogoga razlikovanja tih božanskih atributa bio je, na Balthasarovo ugodno iznenađenje, sam sv. Augustin. ${ }^{25}$ Prema njemu, pravednost i milosrđe u Bogu ne mogu se ni odijeliti ni dokinuti. Božja se svemoć očituje i u tome da je Bog pravedan ako je milosrdan te da je milosrdan ako je pravedan. A ako postoji konflikt između božanske pravednosti i milosrđa, uvijek prevladava pravednost. ${ }^{26}$

Sličnu integraciju Balthasar primjećuje i kod sv. Anzelma: Bog je milosrdan jer je sama dobrota, a sama je dobrota jer je sama pravednost. Prema tomu Bog je istinski milosrdan jer je posve pravedan. Božja pravednost očituje se jednako i onda kad Bog kažnjava grješnike jer to odgovara njihovim djelima, ali i onda kad ih čuva od kazne jer to odgovara samoj Božjoj dobroti. Raspeti Krist, prema sv. Anzelmu, nadilazi svaku aporiju između božanske pravednosti i milosrđa, koji sada povijesno i konkretno, a to znači istinito, supostoje zajedno u Kristu. Krist na križu objava je Božjega spasenja svijeta koje se ne događa samo po Božjem milosrđu nego i po pravednosti koja se sručila na križ i tamo ušla u jedinstvenu harmoniju s milosrđem prema grješnima obznanjujući Božju dobrotu. ${ }^{27}$

Koji je u konačnici Balthasarov stav spram odnosa Božjega milosrđa i pravednosti? On ga poglavito nalazi u Pieperovu konceptu nade: antropološki gledano, antiteza između Božje pravednosti i njegova milosrđa nadiđena je upravo po krjeposti nade jer je nadnaravna nada posve prikladan odgovor na pitanje odnosa tih dvaju božanskih atributa, koja se s ljudske točke gledišta vidi kao neriješeno i nerješivo pitanje. ${ }^{28}$

Nadnaravna nada nije viđenje samo Božjega milosrđa jer bi to bila preuzetnost. Ona nije ni viđenje samo Božje pravednosti jer bi to čovjeka odvelo u očaj. Nadnaravna nada znači moći vidjeti Božje milosrđe kao njegovu pravednost, a Božju

\footnotetext{
${ }^{25}$ Usp. Sperare per tutti, 107.

${ }^{26}$ Usp. AGOSTINO, Esposizioni sui salmi, 32, II, 11 (navedeno prema: A. NITROLA, Trattato di escatologia. 2. Pensare la venuta del Signore, Cinisello Balsamo, 2010., 672.).

${ }^{27}$ Primjer izvornoga razumijevanja Anzelmove teorije zadovoljštine vidi u: I. RAGUŽ, »Intellectus fidei $\ll$ Anzelma Canterburyjskoga s posebnim osvrtom na $\gg$ Cur Deus homo $\ll$, u: ISTI, Teološki fragmenti I., 173-190.

${ }^{28}$ Usp. Sperare per tutti, 113.
} 
pravednost kao njegovo milosrđe. Takva nada jest dužni odgovor na Božju ljubav u Isusu Kristu koji po križu i uskrsnuću objavljuje da je Božje milosrđe spram čovjeka ono prvo iz kojega se tumači Božja pravednost prema čovjeku, ali i da božansko milosrđe može zauzeti mjesto koje pripada božanskoj pravednosti. ${ }^{29}$ Zato je $\gg \mathrm{kr}$ šćanska nada dar preporoda po milosrđu «, iz čega proizlazi da je to zapravo »nada u konačno obraćenje $\ll .^{30}$

\section{Zaključne misli}

Zaključimo našu skicu Balthasarovih promišljanja o nadi u spas svih ljudi i o kristološkoj poduhvaćenosti pakla u nekoliko točaka.

1. Veliki Balthasarov doprinos eshatologiji jest trinitarno-kristološka hermeneutika pakla te primat milosti u toj hermeneutici. Glavno središte eshatologije uvijek je Božje božanstvo, odnosno njegovo gospodstvo i svemoć nad čitavim stvorenjem, njegova ljubav i dobrota spram svakoga čovjeka te vjernost svojim obećanjima. $S$ tom premisom valja pristupiti i pitanjima odnosa Božjega milosrđa i njegove pravednosti. Kristova smrt na križu jedinstvena je žrtva jer je on Bog i čovjek i jer je on božanska Bol uslijed velikosubotnjega paklenoga iskustva napuštenosti od Oca. Bog je dakle po Kristu u pakao ušao najdublje i najdalje u stanju krajnje napuštenosti Sina od Oca. Tako je pakao poduhvaćen odozdo i iznutra s Kristom. Zbog toga je pakao kristološko mjesto, u njega je unesen Kristov križ i s njime Božja ljubav. Pakao je po vazmenom otajstvu postao prigoda milosti jer i onda kad čovjek zauvijek gubi Boga on zapravo ide Bogu ususret. Zato u Kristovu križu Balthasar vidi puninu objave Božje pravednosti koja se ima prevoditi kao njegovo milosrđe. Isto tako Kristov križ, kao i cijelo Kristovo vazmeno otajstvo, na jedinstven način objavljuje da je Bog uvijek čovjekova posljednja stvarnost. On je i pakao za one koji bi ga izgubili. Tim više pakao postaje ozbiljno mjesto ili stanje još veće, posve radikalne muke za grješnika u kojoj mrzi samoga sebe u neizrecivoj agoniji jer onaj koji u paklu želi biti posve i trajno bez Boga sada opet nailazi na Boga koji je solidaran s prokletima.

2. U crkvenom životu pakao danas ne zauzima važno mjesto. Rijetko ga se spominje u teoriji, a gotovo je beznačajan za konkretni kršćanski život. Možda je tomu pridonijela i neželjena posljedica nedavnoga Izvanrednoga jubileja milosrđa u Crkvi. Balthasarova promišljanja pozivaju da se paklu povrati ozbiljnost istine vjere koja mora imati važnu ulogu za svakoga pojedinoga vjernika. Za suvremenu teologiju, duhovnost i pastoral stoga je osobito dragocjen Balthasarov poziv na promišljanje osobnoga karaktera pakla. Recimo to ovako: spasenjsko značenje vjerske istine o

\footnotetext{
${ }^{29}$ Usp. Teodrammatica, V, 268.

${ }^{30}$ Isto, 123.
} 
postojanju pakla tiče se mene kao osobe. Istina o paklu navještaj je koji je uperen isključivo protiv mene kao jedinoga sigurnoga grješnika. Pakao zato trebam vidjeti kao moj pakao, kao realnu posljednju mogućnost moga života. Tako shvaćen pakao neprestano me vraća u nužnu napetost poziva na obraćenje te zato i ozbiljnoga preispitivanja svojih odluka, stavova i djelovanja. Drugim riječima, pakao kao mogućnost moje vječne propasti upozorava me da se moram, dok još to mogu, uvijek iznova odlučivati spram Božje zahtjevnosti u Isusu Kristu. Tako shvaćen osobni karakter pakla potiče me na duhovni boj s grijesima, na stid zbog osobnih grijeha, na kajanje zbog ravnodušnosti i protivljenja spram Boga i na strah od vječne propasti. ${ }^{31}$

3. Na tragu rečenoga postaje razvidno da Balthasar nema nakanu stanjiti ozbiljnost grijeha, zla i ljudske slobode. Zato je jasno osudio apokatastazu kao nebuloznu hipotezu nedostojnu čovjeka. ${ }^{32}$ Prema tomu naš teolog odbija sigurnost uvida da će se pakao jednom jednostavno isprazniti i da će duše osuđenih biti u konačnici pomireni s Bogom. Balthasar izbjegava ustvrditi da će svi biti spašeni. No to ga ne sprječava da, na jedinstven način u suvremenoj teološkoj misli, potakne Crkvu na dužnost nade u spas svih ljudi jer primat milosti i trinitarno-kristološki pristup paklu otvaraju put prema mogućnosti da će Božja spasenjska volja i kod najvećih grješnika, kao i kod onih koji nemaju eksplicitnu vjeru ${ }^{33}$ - dok još to slobodno mogu - naići na kajanje, obraćenje i barem zrno ljubavi. Parafrazirajući poznati skolastički aksiom, ostajući u Balthasarovu duhu, možemo ustvrditi sljedeće: Nada u spas svih ljudi pretpostavlja, ne uništava, već usavršava mogućnost novoga odnosa svakoga grješnika s Bogom. Dakako, nadati se nije isto što i znati. Razlika znanja i nade nipošto nije tek nijansa, nego granica koja povlači crtu između krivovjerja i pravovjerja. Zato je kod našega teologa implicitno uključena mogućnost da bude i suprotno od onoga čemu se nada. Jednom riječju, nitko nije siguran. U toj drami i napetosti između dvaju putova, odnosno dvaju ishoda eshatološkoga suda pojedini je vjernik spram svoga spasenja pesimist, boji se svoje vječne propasti, ali je optimist glede drugih, nadajući se, moleći, trpeći i djelujući tako da se svi spase.

4. Ipak, čitatelj Balthasarovih spisa može steći dojam da je u nekim pitanjima švicarski teolog odlučio ići putem ili-ili. Odnosno da je naglašavajući jedno ipak zapustio drugo. Primat milosti i trinitarno-kristološki pristup eshatologiji konkretno znači da je polazište uvijek Bog, a ne grijeh svijeta. Iz toga može proizići dojam

${ }^{31}$ Usp. I. RAGUŽ, Katolicizam, Đakovo, 2017., 176.

${ }^{32}$ Usp. Teodrammatica, V, 246.

${ }^{33}$ Ovdje valja ukazati na pomak II. vatikanskoga koncila o putovima spasenja koji su samo Bogu znani, a koji daju dodatnu vrijednost Balthasarovu konceptu sveopće nade. Za primjer navodimo: DRUGI VATIKANSKI KONCIL, Dogmatska konstitucija o Crkvi »Lumen gentium «, u: ISTI, Dokumenti, Zagreb, ${ }^{7} 2008$., br. 16. 
apsolutiziranja načela Božje slobode u odnosu na ljudsku slobodu, u smislu da je Božja sloboda neograničena i da ona ima konačnu riječ neovisno o ljudskoj, ograničenoj slobodi. To bi značilo da je moguće misliti kako će zbog apsolutne Božje slobode milost naći način, makar pedagoškom lukavošću ili smicalicom, da obrati grješnu, ograničenu ljudsku slobodu. Tako bi se ušlo u novi problem jer bi se Božjom slobodom posve dokinula ljudska sloboda, što nikad nije bio princip povijesti spasenja. Dojmu problematičnosti nekih Balthasarovih teza doprinose i pitanja na kojima naš teolog inzistira, poput sljedećih: Može li Bog ne spasiti i svoju posljednju ovcu; može li netko stvarno izreći konačno ne Bogu u trenutku kad po smrti sebe i Boga vidi svjetlom Božje nazočnosti i u beskonačnoj poduhvaćenosti pakla; ako će neka duša biti osuđena na pakao, može li se tad govoriti o neuspjehu Božje sveopće spasenjske volje? Ili je ipak riječ o neuspjehu same osobe da ljubavlju odgovori na Božju ljubav u Kristu? Problem ćemo sigurno dodatno zaoštriti ako se pozovemo na još jednu Balthasarovu misao o Kristovoj Velikoj suboti kad $\gg$ utjeha preuzima mjesto očaju, vatra mjesto hladnoći, milosrđe mjesto pravednosti, a čistilište paklu. A sve to za cijenu njegova očaja, koji je neusporediv s ijednim drugim. ${ }^{34}$ Ili pak na ovu misao: »Čistilište je potpuno rođeno onda kad je Sin, sa svojim prolazom kroz pakao unio u stanje pravedno izgubljenih vid milosrda. $\ll^{35}$ Odgovori na pitanja koja su se našla pod ovom točkom zasigurno nadilaze ovo promišljanje, stoga ćemo samo ustvrditi da se ovdje s pravom mogu i dalje očekivati prigovori Balthasarovoj misli. Istodobno se ovdje ponajbolje vidi važnost daljnjih istraživanja kristološko-trinitarne hermeneutike, i samoga pakla te odnosa pakla i čistilišta kod našega teologa.

5. Kao posljednju točku zaključka navodimo dvije perspektive koje ostaju glede nade u spas svih ljudi i doktrinarnih sadržaja o paklu. Prva je ona koju nam je ostavio Balthasar, a druga nam dolazi iz enciklike Spe salvi Benedikta XVI. Prvu perspektivu možemo formulirati kao Balthasarov odgovor na pitanje hoćemo li se svi spasiti:

»To ne znam i nemam nikakvu sigurnost da bih to mogao tvrditi. Ali to istovremeno znači da nemam nikakvu sigurnost ni da se svi ne spašavaju. Sveto je pismo puno navještaja spasenja koje se tiče svih ljudi, puno je navještaja jedinoga Spasitelja Krista koji se utjelovio, umro i uskrsnuo radi svih ljudi i radi njihova spasenja i po kojem je cijeli kozmos, a u njemu na poseban način

\footnotetext{
${ }^{34}$ Teodrammatica, V, 268.

${ }^{35}$ Isto, 311. Usp. isto, 319.
} 
svaki čovjek, započeo nov odnos s Bogom. To je sasvim dovoljno da bi se mogao nadati u spas svih ljudi, bez da time proturječim Riječi Božjoj. $\ll^{36}$

A druga je ona pape Benedikta XVI.:

»Smrću naše životno opredjeljenje postaje konačno i s tim svojim životom dolazimo pred Suca. Naš izbor, koji se oblikovao tijekom čitavog života, može biti različit. Može biti osoba koje su potpuno u srcu uništile svaku želju za istinom i spremnost na ljubav. $U$ takvih se osoba sve pretvorilo u laž, one žive u mržnji i ugasile su u srcu ljubav. Čovjek se zgrozi na samu pomisao da takve osobe postoje, ali upravo takve crte $i$ osobine možemo prepoznati kod nekih osoba iz naše povijesti. Kod takvih pojedinaca ne bi postojala mogućnost ozdravljenja i popravka i u njima bi dobro bilo nepovratno razoreno: to je ono što podrazumijevamo pod riječju pakao. $\ll^{37}$

Obje su te perspektive, dakako, pravovjerne i obje su na neki način granice iza kojih nije moguće ići u odgovoru na pitanje hoće li se svi ljudi spasiti i pritom sigurno ostati unutar svetopisamske objave i istine da smo svi pod Božjim eshatološkim sudom čiji ishod (još) ne poznamo. Ipak, i dalje ostaje pitanje koji od tih dvaju načina bolje i vjernije za teologiju i duhovnost izražava smisao i doseg dogmatskih sadržaja o paklu i dužnosti kršćanske nade u spas svih ljudi.

\footnotetext{
${ }^{36}$ Odgovor formiran na temelju Balthasarova pozivanja na misao L. Locheta. Usp. Sperare per tutti, 80-81.

${ }^{37}$ BENEDIKT XVI., Spe salvi, enciklika, Zagreb, 2008., br. 45, s pozivanjem na Katekizam Katoličke Crkve, br. 1033-1037. Spomenimo ovdje i to da riječ pakao »označava samoću u koju više ne prodire riječ ljubav«. (J. RATZINGER, Uvod u kršćanstvo. Predavanja o Apostolskom vjerovanju, Zagreb, $\left.{ }^{5} 2002 ., 275.\right)$
} 


\section{A SKETCH OF THE CHRISTOLOGICAL-TRINITARIAN HERMENEUTICS OF HELL AND THE DUTY OF HOPE FOR THE SALVATION OF ALL PEOPLE IN THE THOUGHT OF H. U. VON BALTHASAR}

\section{Boris VULIĆ*}

Summary: It seems that the last great truly theological discussion was conducted around the thesis of the Swiss theologian Hans Urs von Balthasar on the hope for salvation of all people. The aim of the article is primarily to remind of the basic tenets of this proposal. Thus, in the first chapter, we present the New Testament places and theological moments which this Swiss theologian takes as starting points and justifications for his conviction of the duty of Christian hope in the universal salvation. However, the underlying thesis of the article is that the ultimate backdrop of such hope is Balthasar's Christological-Trinitarian hermeneutics of hell, in which hell becomes seized by Christ and is therefore a Christological place of grace. It is this final backdrop, whose sketch we bring in the second chapter, which most representations in the Croatian language fail to recognize as a fundamental premise of hope for the salvation of all people. The mentioned original hermeneutics brought Balthasar to the conviction that God's mercy through the cross of Christ occupies the place of righteousness, which is the subject of the third and final chapter of the article. In the concluding remarks, we point to the important contributions of Balthasar's reflections on universal hope, like the severity of the religious truth about hell, the personal character of the possibility of hell (hell for me) and of God Who is always man's last reality, even when he is eternally lost. We also reveal some questionable or problematic places of Balthasar's thought which should be recognized as new perspectives for further critical research.

Keywords: Hans Urs von Balthasar, hope, universal salvation, Trinity, the Cross of Christ, hell, mercy, righteousness.

\footnotetext{
* Asst. Prof. Boris Vulić, Ph. D., Catholic Faculty of Theology in Đakovo, J. J. Strossmayer University of Osijek, P. Preradovića 17, P.O. box 54, 31400 Đakovo, Croatia, vulic@me.com
} 